\title{
Pericarp development in the macaw palm Acrocomia aculeata (Arecaceae)
}

\author{
Desenvolvimento do pericarpo em macaúba [Acrocomia aculeata (Arecaceae)]
}

\author{
Sarah Barbosa Reis ${ }^{1}$, Maria Olivia Mercadante-Simões ${ }^{1}$ \& Leonardo Monteiro Ribeiro ${ }^{2,3}$
}

\begin{abstract}
The anatomy of the pericarp of the macaw palm (Acrocomia aculeata) was followed during development. Ovaries of flowers collected at anthesis of the bracts as well as pericarps were evaluated at different development phases using traditional plant anatomy techniques. The ovary wall has two meristematic regions, one adjacent to the external epidermis and the other surrounding the seminal cavity. The external meristematic region gives rise to the woody exocarp, and the internal meristematic region is responsible for thickening of the oily/fibrous mesocarp as well as the hard endocarp. Sclerification of the exocarp and endocarp occurs approximately 70 days after anthesis and defines the final fruit volume. Lignification of the exocarp cell layers is incomplete, lending porosity to the structure. Numerous canals develop in the mesocarp that are formed by the fusion of raphide-containing idioblasts. Lignification of the sclereids and their generally random arrangement confers impermeability and rigidity to the endocarp. In mature fruits, lipidic reserves are observed in parenchymatic cells of the mesocarp, and the germination pore in the endocarp is composed of parenchymatic cells.
\end{abstract}

Key words: fruit ontogenesis, lipids, sclerification.

\section{Resumo}

O objetivo deste trabalho foi caracterizar anatomicamente o pericarpo da macaúba (Acrocomia aculeata) durante seu desenvolvimento. Foram avaliados ovários de flores coletadas no dia da antese da bráctea e pericarpos em diferentes fases de desenvolvimento, por meio de técnicas usuais em anatomia vegetal. A parede ovariana apresenta duas regiões meristemáticas, uma adjacente à epiderme externa e outra que envolve a cavidade seminal. A região meristemática externa origina o exocarpo lenhoso. A região meristemática interna é responsável pelo espessamento do mesocarpo oleaginoso-fibroso e do endocarpo pétreo. A esclerificação do exocarpo e do endocarpo, que ocorre próximo dos 70 dias da antese, define o volume final do fruto. A lignificação das células do exocarpo é incompleta, conferindo porosidade à estrutura. No mesocarpo se desenvolvem numerosos canais, formados pela fusão de idioblastos contendo ráfides. No endocarpo, a lignificação e a orientação das esclereídes em várias direções, conferem impermeabilidade e rigidez. Nos frutos maduros, a reserva lipídica se localiza em células parenquimáticas do mesocarpo e observa-se a presença de poro germinativo no endocarpo, composto por células parenquimáticas.

Palavras-chave: ontogênese do fruto, lipídios, esclerificação.

\section{Introduction}

The macaw palm [Acrocomia aculeata (Jacq.) Lodd. ex Mart.] is widely distributed throughout Brazil, and its oleaginous fruits have traditionally been used in foods and for manufacturing of soaps (CETEC 1983; Motta et al. 2002). The high productivity of this palm, the quality of its oil, and its drought-resistance have created interest in its agro-industrial uses, including for the production of bio-fuels (CETEC 1983; Moura et al. 2010).

\footnotetext{
${ }^{1}$ Unimontes, Depto. Biologia Geral, Lab. Anatomia Vegetal, Vila Mauricéia s/n, 39401-089, Montes Claros, MG, Brasil

${ }^{2}$ Unimontes, Depto. Biologia Geral, Lab. Micropropagação, Vila Mauricéia s/n, 39401-089, Montes Claros, MG, Brasil.

${ }^{3}$ Author for correspondence: leomrib@hotmail.com
} 
Pecularities in the cells of the pericarp may confer economic importance to the fruit (Sousa 2006) influencing its reproduction, use and cultivation. The protection provided by the exocarp of $A$. aculeata, due to its mechanical resistance and limited permeability, influences post-harvest bacterial degradation of the oils present in the mesocarp (CETEC 1983). The fibrous nature of the pulp and the presence of nutrients reflects the types of cells found in the mesocarp (Souza 2006; Vegas et al. 2008), which in turn influence the commercial value of the fruits and the types of the industrial processes required for oil extraction (CETEC 1983). The hard endocarps that are common features of palm fruits influence their relationships with disperser and predator species (Essig 1999) and can determine physical dormancy (Orozco-Segovia et al. 2003), and in the specific case of the macaw palm these structure have excellent potential for energy generation (CETEC 1983; Silva et al. 1986).

As such, the present work examined the anatomical development of the pericarp of Acrocomia aculeata to provide more detailed information about its structure that should aid studies examining post-harvesting storage and seed germination as well as contribute to programs of genetic improvement of this species to produce larger fruits with more oil and calorific power.

\section{Materials and Methods}

The plant material used was obtained from Acrocomia aculeata palms growing on the campus of the Universidade Estadual de Montes Claros in Minas Gerais State, Brazil, between the months of September/2008 and November/2009. The ovaries examined where removed from flowers obtained on the first day of anthesis of the bracts, and the fruit pericarps were collected every two days during the first two weeks, and then every fourth day from the third to eleventh week of development (when the lignification of the exocarp and endocarp were complete). The presence of reserve compounds was investigated using histochemical tests of mature fruits collected after natural abscission. In preparation for the anatomical evaluations, the material was fixed in FAA, stored in $70 \%$ ethanol, dehydrated in an ethanol series, and embedded in paraffin using butanol as the solvent (Johansen 1940). Transversal and longitudinal sections were made at $10 \mu \mathrm{m}$ thicknesses in a rotary microtome, stained with astra blue and Safranin (Bukatsch 1972) as well as toluidine blue and hematoxylin (Johansen 1940), and were subsequently mounted on permanent slides using acrylic resin. The classification and description of pericarp will be according Roth (1977).

Part of the freshly collected material was transversally sectioned and submitted to histochemical tests that could identify total lipids using Sudan III (Johansen, 1940), proteins using xilidine Pounceau (O’Brien \& McCully 1981), starch using lugol solution (Jensen 1962), mucilage using tannic acid (Pizzolato \& Lillie 1973), and tannins using vanillin chloride (Mace and Howell 1974). The slides were observed under a Nikon 250 light microscope and photomicrographs were taken using a coupled Canon A620 digital camera.

\section{Results}

The ovary of macaw palm is superior, tricarpellary, syncarpous and has a single ovule in each locule with axile placentation. In the carpels mesophyll it is possible to distinguish an external and a median regions, and an inner adaxial meristem (Fig. 1a). The external epidermis is uniseriate, is composed of cubical cells, and has long, multiseriate tector trichomes with elongated cells and thin cell walls (Fig. 1b). Globoid meristematic-appearing cells were observed in the external region of the mesophyll interspersed with radially elongated cell bundles (Fig. 1b). The median region of the mesophyll is predominantly composed of parenchymatic cells, and tannin-containing idioblasts as well as raphidecontaining idioblasts were seen (the latter cells being positioned more externally) (Fig. 1a,c). The vascularization, which started in the receptacle, was distributed diffusely through the mesophyll (Fig. 1a,c) and was composed of collateral vascular bundles (Fig. 1c,d). An adaxial meristem (Fig. 1a,d) correspond to the internal region of the mesophyll, present periclinal divisions. The internal epidermis was uniseriate and composed of cubical cells (Fig. 1d).

It was possible to observe at two, 20, and 70 days after anthesis the principal events that would determine the characteristics of the mature pericarp. After two days of development, the initial stages of the atrophy of two of the carpels in the fruit could be seen. As well as the differentiation of the exocarp that initiated in the external epidermis and the 

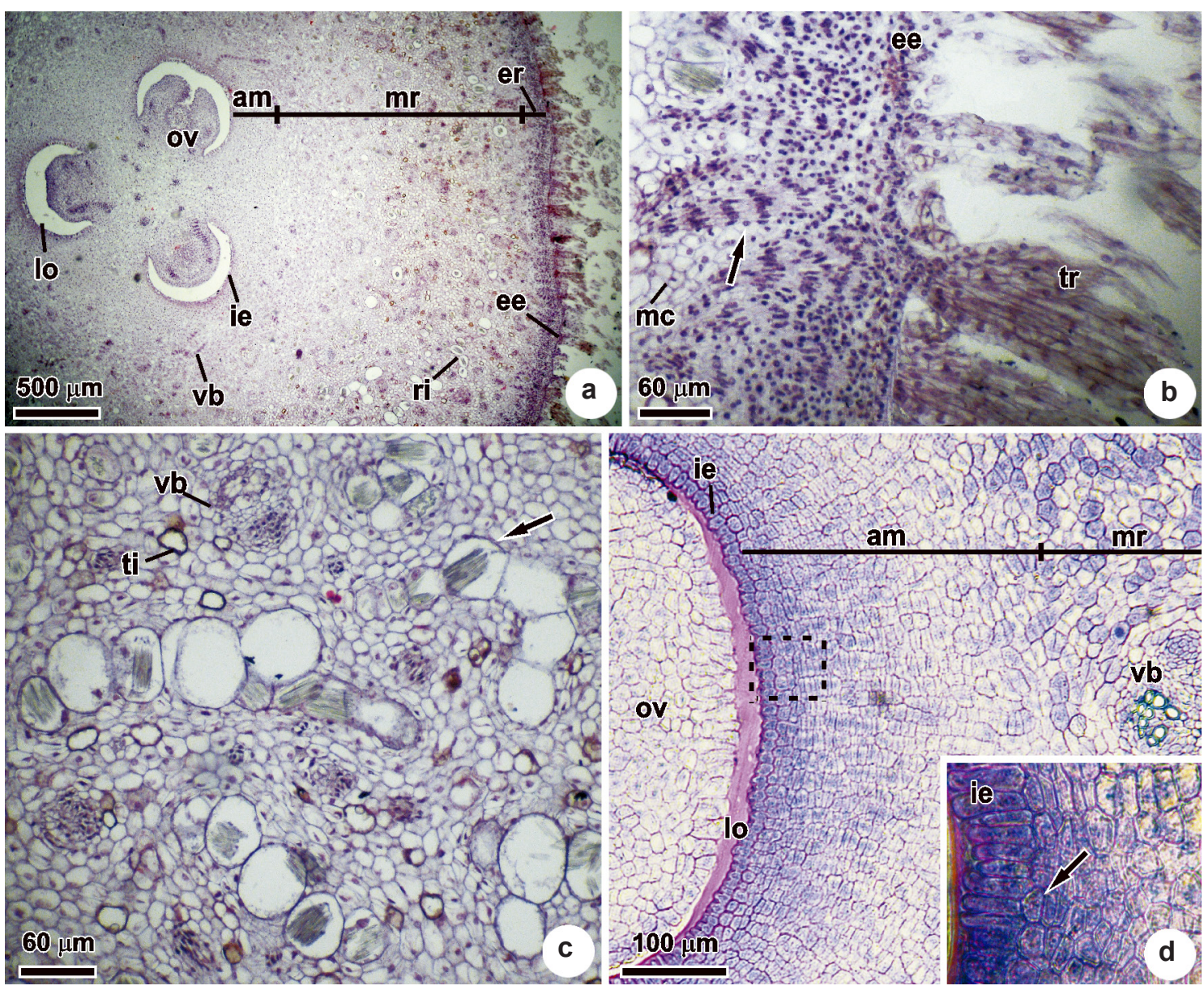

Figure 1 - Transversal sections of the ovary of Acrocomia aculeata. a. Panoramic view, indicating the different anatomical regions. b. External region of the mesophyll, indicating bundles of radially elongated cells (arrow). c. Median region of the mesophyll, indicating raphide-containing idioblasts (arrow). d. Adaxial meristem, corresponding to the internal region of the mesophyll, indicating cells undergoing periclinal divisions (arrow); internal region of the adaxial meristem (box). am, adaxial meristem; ee, external epidermis; er, external region of the mesophyll; ie, internal epidermis; lo, locule of the ovary; mc, meristematic cells; mr, median region of the mesophyll; ov, ovule; ri, raphide-containing idioblast; ti, tannin-containing idioblast; tr, trichome; vb, vascular bundle.

external region of the mesophyll showing bundles of radially elongated cells (Fig. 2a). The trichomes show accumulations of tannins and the epidermis remains uniseriate (Fig. 2b). The mesocarp differentiates from the median region of the ovarian carpel mesophyll where increases in cell volume and fusion of the raphide-containing idioblasts were observed, the latter resulting in the formation of canals (Fig. 2a,c). The endocarp begins its differentiation, in the adaxial meristem, and cells could be seen there dividing in all directions; cells in the internal epidermis only divide anticlinally maintaining its uniseriate nature (Fig. 2d).
At 20 days of development, continuity of the differentiation of all of the pericarp regions was observed. In the exocarp, the remaining trichomes had become lignified, and stomata could be seen in the external epidermis as well as raphide-containing idioblasts in the parenchymatic layer (Fig. 3a-b). Bundles of radial sclerenchymal fibers could be seen in their initial stages of lignification, and these were bordered by isodiametric cells. In the mesocarp/endocarp transition, the external layers of the adaxial meristem add new mesocarp elements such as parenchymatic cells, tannin and raphide containing idioblasts, vascular bundles, and bundles of 

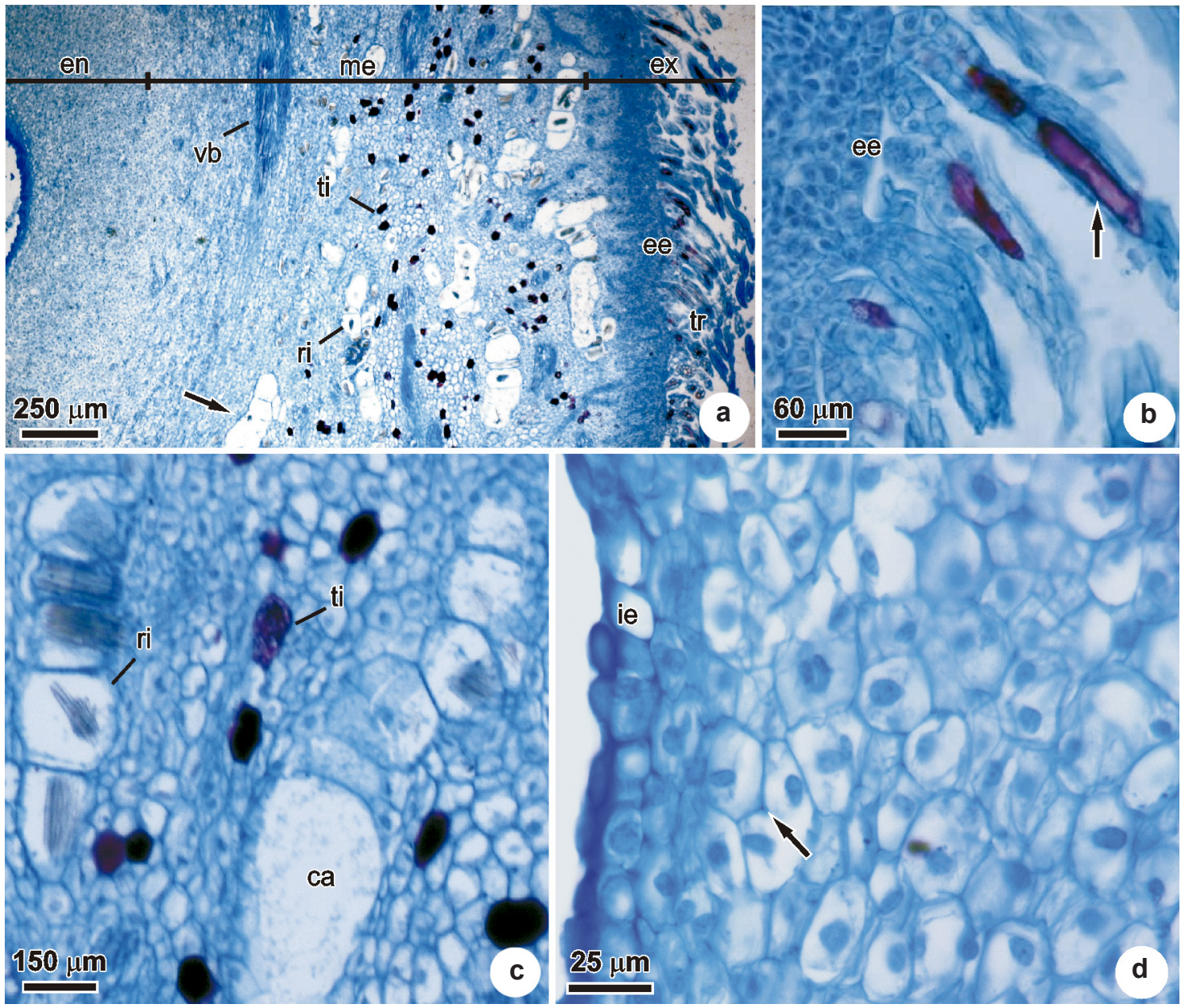

Figure 2-Longitudinal sections of the pericarp of Acrocomia aculeata, after two days of development. a. Panoramic view, showing the exocarp (epidermis and external mesocarp), mesocarp and endocarp (internal mesocarp and epidermis); the arrow indicates a canal. b. Exocarp indicating trichomes with accumulations of tannins (arrow). c. Mesocarp, indicating the formation of canals through the fusion of raphide-containing idioblasts. d. Endocarp (originated from the adaxial meristem and epidermis) indicating dividing cells (arrow). ca, canals; ee, external epidermis; en, endocarp; ex, exocarp; ie, internal epidermis; me, mesocarp; ri raphide-containing idioblast; ti, tannincontaining idioblast; tr, trichome; vb, vascular bundle.

sclerenchymal fibers (Fig. 3c). The cells of the internal layers of the adaxial meristem divide in all directions, contributing to the expansion of the endocarp (Fig. 3d). An accumulation of tannins was observed in the cell layer adjacent to the internal epidermis. The epidermal cells divided anticlinally and thus did not contribute to the thickening of the endocarp.

At 70 days of development, the majority of trichomes are falled. In the parenchymatic region, of the exocarp that is located adjacent to the epidermis, canals are formed from the fusion of raphidecontaining idioblasts. Internally, regions with lesser degrees of lignification occur due to the presence of parenchymatic cells and sclereids among the radial fiber bundles (Fig. 4a). Increases in the volumes of the mesocarp canals could also be noted (Fig. 4b). The external layers of the adaxial meristem, located in the transition region between the mesocarp and the endocarp continued in activity, and continued to thicken the mesocarp (Fig. 4c). In the endocarp the differentiation of sclerids could be seen, with evident pits, and oriented in many different directions, and these structures serve to harden it. The cells of the internal layers of the endocarp accumulate tannins 


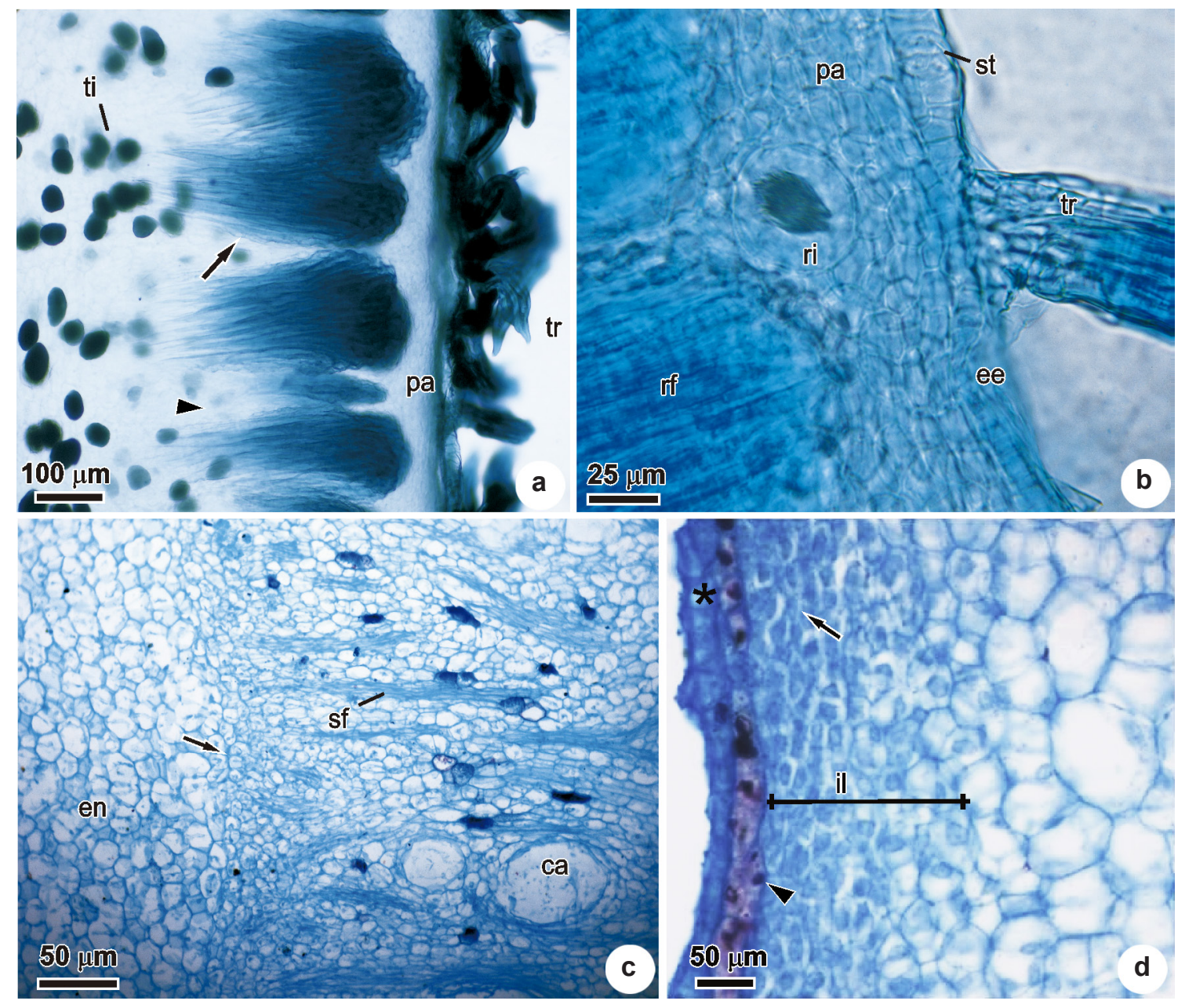

Figure 3 - Transversal sections of the pericarp of Acrocomia aculeata after 20 days of development. a. Exocarp, indicating bundles of radial sclerenchymal fibers in their initial stages of lignification (arrow) and isodiametric cells (head arrow). b. Exocarp, indicating the parenchymatic layer. c. External layers of the adaxial meristem, in the transition region of the mesocarp-endocarp giving rise to new mesocarp elements (arrow). d. Endocarp, indicating dividing cells (arrow); a layer with accumulated tannins (head arrow), and epidermal cells undergoing anticlinal divisions (asterisk). ca, canal; ee, external epidermis; en, endocarp; il, internal layers of the adaxial meristem; pa, parenchyma; rf, radial fiber bundles; ri, raphide-containing idioblasts; sf, sclerenchymal fiber bundles; st, stomata; ti, tannin-containing idioblast; tr, trichome.

and cease any meristematic activity (Fig. 4d). The volume of the fruit approximates that of the mature fruit in this phase of development, its expansion being restricted by the sclerification of both the exocarp and endocarp.

At approximately 380 days after anthesis of the bracts, the pericarp of the mature fruit is very similar to that seen at 70 days, with a woody exocarp, a fibrous mesocarp, and a hardened endocarp with a germination pore composed of fibrous tissue (Fig. 5a). The fibrous/oily mesocarp shows lignification of the sclerenchymal fiber bundles and tracheal elements (Figs. 5b), as well as the accumulation of oils in the parenchymatic cells (Figs. 5c) and mucilage in the canals. A discrete accumulation of proteins was observed in the parenchymatic cells, but no starch deposition was evident during any of the developmental phases. The hard nature of the endocarp is determined by the presence of sclereids, with thick and highly lignified cell walls. 

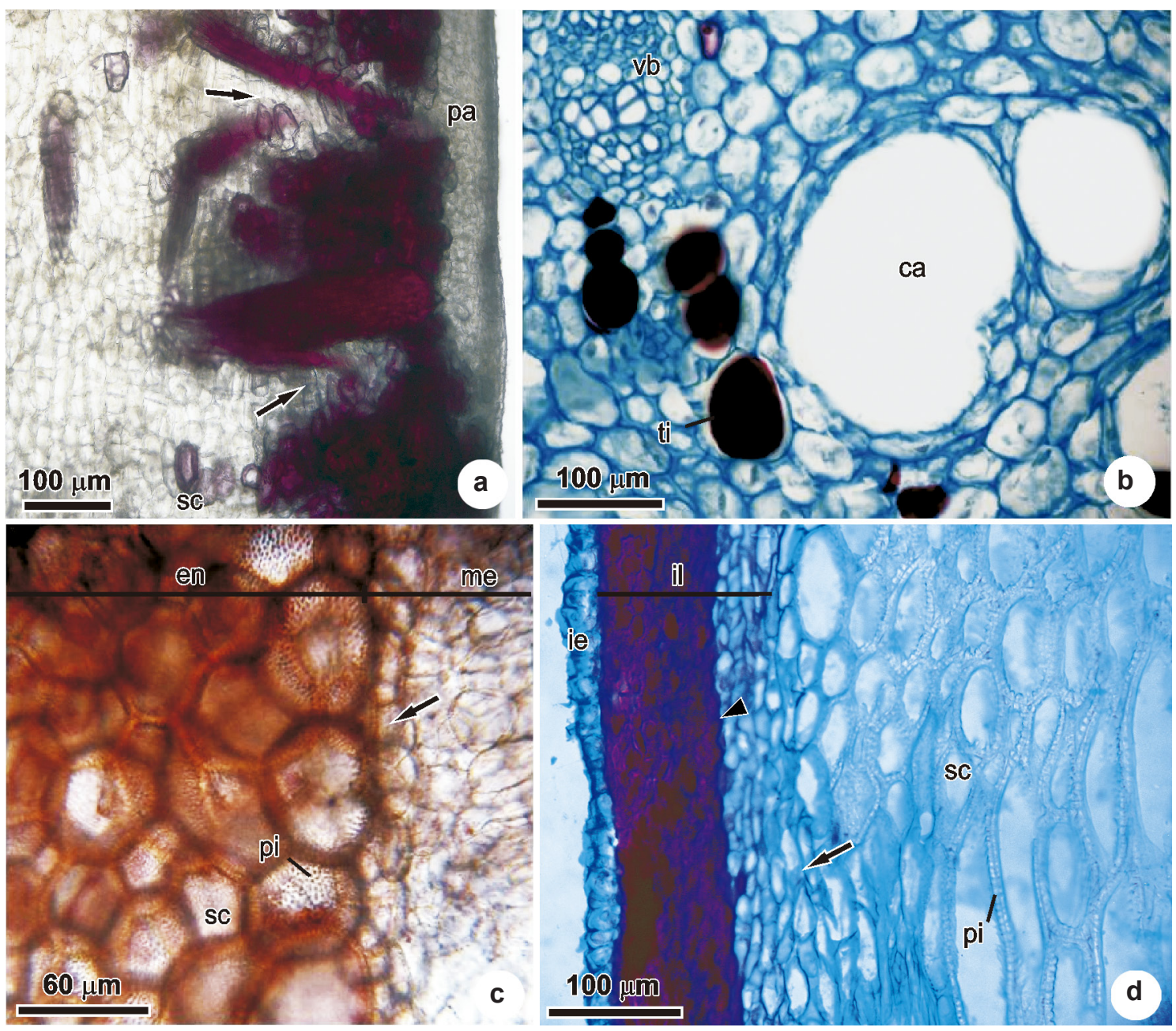

Figure 4- Longitudinal sections of the pericarp of Acrocomia aculeata after 70 days of development. a. Exocarp, indicating regions with lesser degrees of lignification (arrows). b. Mesocarp, indicating canals with increasing volumes. c. Endocarp, indicating the external layers of the adaxial meristem responsible for mesocarp thickening (arrow). d. Endocarp, indicating the meristematic region that adds cells to the endocarp (arrow); and cells with accumulations of phenolic compounds (head of arrow). ca, canal; en, endocarp; ie, internal epidermis; il, internal layers of the endocarp; me, mesocarp; pa, parenchyma; pi, pits; sc, sclereids; ti, tannin-containing idioblast; vb, vascular bundle.

\section{Discussion}

The superior, tricarpellary, syncarpous ovary of macaw palm, with a single ovule with axile placentation are typical characteristic of the Arecaceae (Uhl \& Moore 1971; MercadanteSimões et al. 2006; Dransfield et al. 2008; Judd et al. 2009). Raphide-containing idioblasts have been seen in the ovaries of palm species of the genera Licuala Thunb. (Barfod et al. 2003) and Chamaedorea Willd. (Askgaard et al. 2008). The process of canal formation from raphidecontaining idioblasts has been reported in three species of Astrocaryum G. Mey. (Arecaceae) (Vegas et al. 2008) and tannin-bearing idioblasts were reported in the flowers of Geonoma interrupta Mart. (Stauffer et al. 2002) and in the fruits of Pelagodoxa Becc. (Chapin et al. 2001) and Oenocarpus Mart. (Mendonça et al. 2008). Ovaries of palms are often seen to abort during the first phases of fruit development, characterizing a pseudo-monomerous condition (Uhl \& Moore 1971; Orozco-Segovia et al. 2003) that gives rise to drupes with a single seed in the pyrene (Souza 2006). In the case of the macaw palm, the fruits 


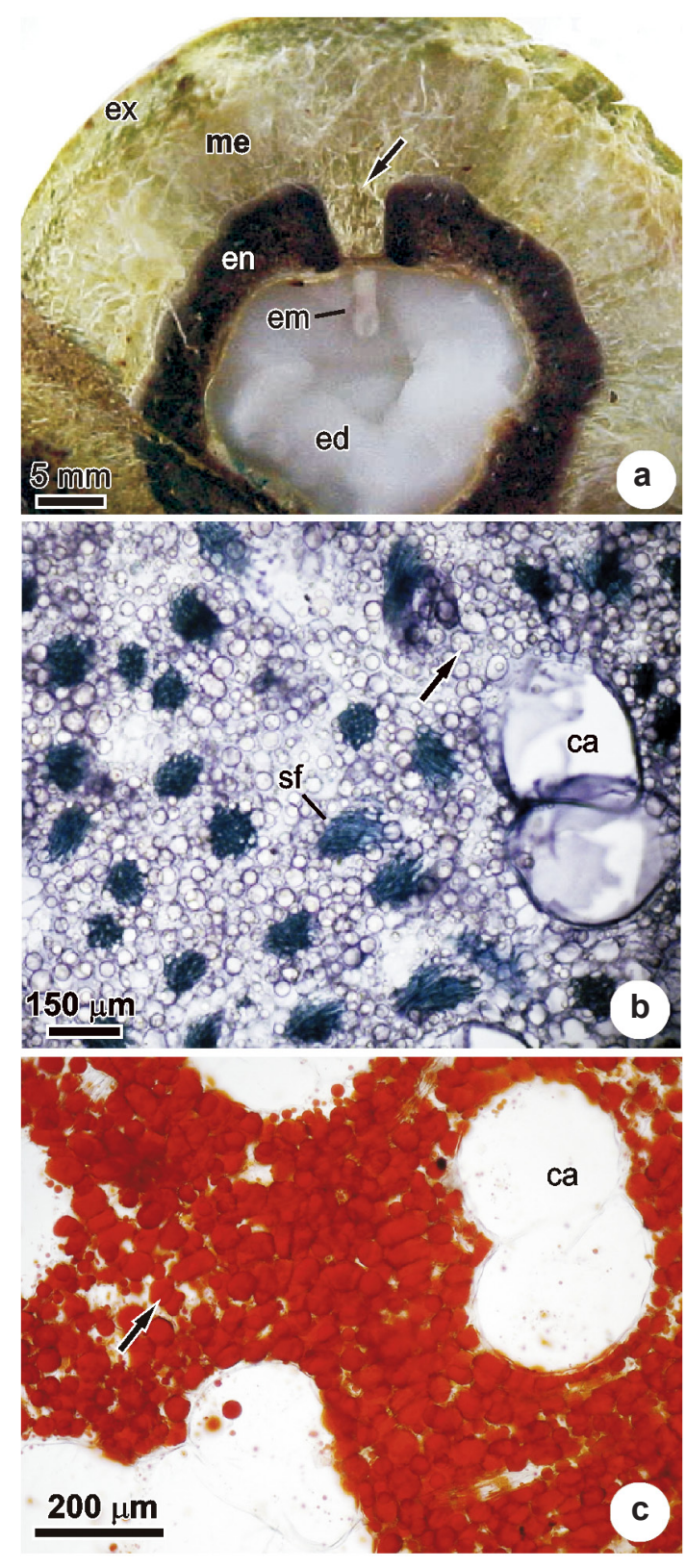

Figure 5-Transversal sections of the mature fruit of $A$. aculeata. a. General view, indicating the germination pore (arrow). b. Mesocarp indicating sclerenchymatic fibers. c. Mesocarp, indicating lipid containing cells. ca, canals; ed, endosperm; em, embryo; en, endocarp; ex, exocarp; me, mesocarp; sf, bundle of sclerenchymal fibers.

can be considered drupoids, due to the occasional occurrence of more than one seed in the pyrene (Souza 2006).

The lignification of the exocarp in palms is due to the presence of sclerenchymal fiber bundles and sclereids in the subepidermal region (Essig 1999; Vegas et al. 2008). The brittle nature of the woody exocarp of the macaw palm results from the presence of groups of sclereids interspersed in the fiber bundles that generate lines of weakness (a characteristic of the species of the subtribe Linospadicinae) (Essig 2002). This type of anatomy may favor the penetration of bacteria that can degrade the mesocarp oils - and this represents an important post-harvest problem with the fruits of the macaw palm (CETEC 1983).

The fibrous nature of the macaw palm mesocarp (Lorenzi et al. 2004) is due to the conspicuous presence of sclerenchymal fibers, as was also observed in species of Astrocaryum G. Mey. (Vegas et al. 2008). The presence of mucilage in the fruit pulp probably contributes to maintaining its water content, but will influence the extraction and quality of its oil. The accumulation of lipids in palm mesocarp is quite common (Sambanthamurthi et al. 2000; Mendonça et al. 2008), and a $16.5 \%$ oil content has been reported for this structure in the macaw palm (Hiane et al. 2005).

Fruit development in Acrocomia aculeata is very slow (Scariot \& Lleras 1991) and the formation of oils occurs only very near to the moment of abscission. As this oil is susceptible to degradation (CETEC 1983; Hiane et al. 2005) additional studies will be needed that can associate the development phases of the fruit with the accumulation of lipids; this information could help define harvesting strategies appropriate to maintaining the post-harvest quality of the fruit/oil.

The mixed origin of the macaw palm endocarp from the internal mesophyll and internal epidermal regions requires the use of the term endocarp sensu lato for the covering of the woody pyrene but not sensu stricto, as origin is not exclusively epidermal (Roth 1977). Endocarp sensu lato is also observed in Oenocarpos minor Mart. that is composed of layers of mesocarpic fibers adhering to the seed integument (Mendonça et al. 2008). The high specific weight of the macaw palm endocarp makes it attractive as a potential source of renewable energy (CETEC 1983; Silva et al. 1986) and its density is a consequence of the intense lignification of the cell walls of the sclerenchymal fibers and their orientation in many directions. The endocarps of fruits of species of Astrocaryum of the tribe Linospadicinae (Essig 
2002) have fibers and brachysclereids (Vegas et al. 2008). In spite of references to the hard endocarp as being the cause of dormancy in palm tree seeds through the limitation of the fluxes of water and gases to the seed, is possible that are no severe restrictions to the fluxes of these substances in Acrocomia aculeata as the endocarp was not sclerified in the region of the germination pore.

Our observation indicated that the ovary of the macaw palm is very specialized, and there were precocious indications of those regions that would differentiate into the different tissues of the pericarp. The final volume of the fruit is defined by sclerification of the exocarp and endocarp approximately 70 days after anthesis. The porosity of the exocarp is the result of alternating regions with different degrees of lignification, and it woody nature is due to the compact arrangement of the sclerids. Abundant lipidic reserves develop during the final phases of fruit development and are stored in the parenchymatic cells of the mesocarp.

\section{Acknowledgements}

The authors would like to thank the Fundação de Amparo a Pesquisa do Estado de Minas Gerais FAPEMIG for the grants that made this work possible.

\section{References}

Askgaard, A.; Stauffer, F.W.; Hodel, D.R. \& Barfod, A.S. 2008. Floral structure in the neotropical palm genus Chamaedorea (Arecoideae, Arecaceae). Anales del Jardín Botánico de Madrid 65: 197-210.

Barfod, A.S.; Burholt, T. \& Borchsenius, F. 2003. Contrasting pollination modes in three species of Licuala (Arecaceae: Caryphoideae). Telopea 10: 207-223.

Bukatsch, F. 1972. Bermerkungen zur doppelãrbung Astrablau-Safranin. Mikrokosmos 61: 255.

Chapin, M.H.; Essig, B.F. \& Pintaud, J. 2001. The morphology and histology of the fruits of Pelagodoxa (Arecaceae): taxonomic and biogeographical implications. Systematic Botany 26: 779-785.

Dransfield, J.; Uhl, N.W.; Asmussen, C.B.; Baker, W.J.; Harley, M.M.; Lewis, C.E. 2008. Genera PalmarumThe evolution and classification of palms. Richimond, London: Royal Botanical Gardens, Kew. 732p.

Essig, F. 2002. A systematic histological study of palms fruit. VI. Subtribe Linospadicinae (Arecaceae). Brittonia 54: 196-201.

Essig, F.B. 1999. Trends of specialization in the palm pericarp. Memors of The New York Botanical Garden 83: 73-77.
CETEC - Fundação Centro Tecnológico de Minas Gerais. 1983. Produção de combustíveis líquidos a partir de óleos vegetais. Vol 1. CETEC, Belo Horizonte.151p.

Hiane, P.A.; Filho, M.M.R.; Ramos, M.I.L. \& Macedo, M.L.R. 2005. Bocaiúva, Acrocomia aculeata (Jacq.) Lodd., pulp and kernel oils: characterization and fatty acid composition. Brazilian Journal of Food Technology 8: 256-259.

Jensen, W.A. 1962. Botanical histochemistry: principles e practice. W.H. Freeman, San Francisco. 408p.

Johansen, D.A. 1940. Plant microtechnique. MacGraw Hill, New York. 523p.

Judd, W.S; Campbell, C.S.; Kellog, E.A.; Stevens, P.F. \& Donoghue, M.J. 2009. Sistemática vegetal: um enfoque filogenético. Artmed, Porto Alegre. 632p.

Lorenzi, H.; Souza, H.M; Cerqueira, L.S.C.; Costa, J.T.M. \& Ferreira, E. 2004. Palmeiras brasileiras e exóticas cultivadas. Instituto Plantarum, Nova Odessa. 416p.

Mace, M.E. \& Howell, C.R. 1974. Histochemistry and identification of condesed tannin precursor in roots of cotton seedlings. Canadian Journal of Botany 52: 2423-2426.

Mendonça, M.S.; Oliveira, A.B.; Araújo, M.G.P. \& Araújo, L.M. 2008. Morfo-anatomia do fruto e semente de Oenocarpus minor Mart. (Arecaceae). Revista Brasileira de Sementes 30: 90-95.

Mercadante-Simões, M.O.; Fonseca, R.S.; Ribeiro, L.M. \& Nunes, Y.R.F. 2006. Biologia reprodutiva de Butia capitata (Mart.) Beccari (Arecaceae) em uma área de cerrado no norte de Minas Gerais. Unimontes Científica 8: 143-149.

Motta, P.E.F.; Curi, N. \& Oliveira-Filho, A.T. de; Gomes, J.B.V. 2002. Ocorrência da macaúba em Minas Gerais: relações com atributos climáticos, pedológicos e vegetacionais. Pesquisa Agropecuária Brasileira 37: 1023-1031.

Moura, E.F.; Ventrella, M.C. \& Motoike, S.Y. 2010. Anatomy, histochemistry and ultrastructure of seed and somatic embryo of Acrocomia aculeata (Arecaceae). Scientia Agricola 67: 375-495.

O'Brien, T.P. \& McCully, M.E. 1981. The study of plant structure principles and select methods. Melbourne, Termarcarphi Pty. 45p.

Orozco-Segovia, A; Batis, A.I.; Rojas-Aréchiga, M \& Mendoza, A. 2003. Seed biology of palms: a review. Palms 47: 79-94.

Pizzolato, T.D. \& Lillie, R.D. 1973. Mayer's tannic acid-ferric chloride stain for mucins. Journal of Histochemistry and Cytochemistry 21: 56-64.

Roth, I. 1977. Fruits of angiosperms. Gebrüder Borntraeger, Berlin. 614p. 
Sambanthamurthi, R.; Sundran, K. \& Tan, Y. 2000. Chemistry and biochemistry of palm oil. Progress in Lipid Research 39: 507-558.

Scariot, A.O. \& Lleras, E. 1991. Reproductive biology of the palm Acrocomia aculeata in Central Brazil. Biotropica 23: 12-22.

Silva, J.C. \& Barrichelo, L.E.G.; Brito, J.O. 1986. Endocarpos de babaçu e de macaúba comparados a madeira de Eucalyptus grandis para a produção de carvão vegetal. Ipef 34: 31-34.

Souza, L.A. 2006. Anatomia do fruto e da semente. Ed. UEPG, Ponta Grosa. 196p.
Stauffer, F.W.; Rutishauser, R. \& Endress, P.K. 2002. Morphology and development of the female flowers in Geonoma interrupta (Arecaceae). American Journal of Botany 89: 220-229.

Uhl, N.W. \& Moore, E. 1971. The palm gynoecium. American Journal of Botany 58: 945-992.

Vegas, C.; Millián, B.; Pintaud, J.C. \& Kahn, F. 2008. Anatomía del fruto y perianto en species peruanas del género Astrocaryum (Arecaceae): descripción e importância taxonômica. Revista Peruana de Biología 15: 85-96. 